\title{
Vaikų epilepsijos gydymas kaliozotomija: du klinikiniai atvejai ir literatūros apžvalga
}

\author{
R. Matonyté* \\ S. Ročka** \\ J. Grikiniené $\dot{e}^{* * *}$ \\ *Vilniaus universiteto \\ Medicinos fakultetas \\ **Vilniaus universiteto \\ Medicinos fakultetas; \\ Klinikines medicinos institutas, \\ Neurologijos ir neurochirurgijos \\ klinika, Neurochirurgijos centras \\ $* * *$ Vilniaus universiteto \\ Medicinos fakultetas; \\ Klinikines medicinos institutas, \\ Vaiku ligu klinika, \\ Pediatrijos centras
}

\begin{abstract}
Santrauka. Epilepsija yra viena iš dažniausių lètinių vaikų ligų. Aktyvios vaikų epilepsijos paplitimas Lietuvoje, $2018 \mathrm{~m}$. duomenimis, - 6,1/1000 vaikų. Nauji epilepsijos atvejai dažniausiai nustatomi vaikų arba vyresnių žmonių populiacijose. Epilepsija yra daugiaetiologinė liga ir pasireiškia labai ịvairiais epilepsijos priepuoliais, kurių suvaldymas yra svarbiausias siekis gydant epilepsiją. Neslopinami priepuoliai gali sukelti vaiko kalbos, pažintinių funkcijų ir elgesio raidos sutrikimus - epilepsinę encefalopatiją. Veiksmingas epilepsijos gydymas vaikams ne tik pagerina sveikatos būklę, bet ir mažina socialinę atskirtį bei padeda integruotis ị edukacinę veiklą. Tačiau, net ir anksti diagnozavus ligą ir paskyrus tinkamą gydymą vaistais nuo epilepsijos, epilepsijos priepuoliai išlieka 20-40 \% sergančiųjų. Tokiems pacientams gali būti veiksmingas chirurginis epilepsijos gydymas - rezekcinès arba funkcinès (paliatyviosios) operacijos. Rezekcinis gydymas pagrịstas prielaida, kad epileptogeninès zonos pašalinimas apsaugo nuo priepuolių. Deja, kai kuriais atvejais epileptogeninè zona išlieka neaiški net ir po daugelio galvos smegenų tyrimų arba nesutampa su anatominio pažeidimo zona. Tokiu atveju rezekcinė operacija negali būti pritaikyta. Vienas iš veiksmingų sunkiai gydomos epilepsijos priepuolių kontrolès būdų yra paliatyvi chirurginė operacija - kaliozotomija (didžiosios smegenų jungties (corpus callosum) perpjovimas). Didžioji smegenų jungtis yra svarbiausia jungtis nerviniam impulsui plisti tarp abiejų smegenų pusrutulių, todèl jos atjungimas sutrikdo impulso plitimą tarp pusrutulių, taip sustabdydamas priepuolio generalizaciją. Klinikinių tyrimų duomenimis, kaliozotomija yra veiksminga iki 80-90 \% operuotų pacientų - priepuoliai išnyksta arba reikšmingai sumažèja jų dažnis ir sunkumas.

Aprašomi du pediatriniai pacientai, gydyti Vilniaus universiteto ligoninės Santaros klinikų Vaikų neurologijos ir neurochirurgijos skyriuose, kuriems buvo atlikta kaliozotomija ir palyginamos šių klinikinių atvejų išeitys su naujausių klinikinių tyrimų rezultatais.
\end{abstract}

Raktažodžiai: vaistams atspari epilepsija, vaikai, epilepsijos operacija, kaliozotomija.

\section{IVADAS}

Vaikų epilepsija yra lètinė polietiologinè neurologinė liga, kuri diagnozuojama, kai pasireiškia mažiausiai du neprovokuoti epilepsijos priepuoliai, kuriuos skiria daugiau nei 24 valandos, arba kai pasireiškia vienas neprovokuotas priepuolis, kai jo pasikartojimo rizika yra ne mažesnè nei $60 \%$, arba kai pakanka duomenų specifinio epilepsijos

\author{
Adresas: \\ Jurgita Grikiniené \\ Všl Vaiku ligoninè, Vilniaus universiteto ligoninès Santaros \\ kliniku filialas, Pediatrijos centras, Vaiku neurologijos skyrius \\ Santariškiu g. 7, LT-08406 Vilnius \\ El.paštas jurgita.grikiniene@mf.vu.lt
}

sindromo diagnozei. Nors šios ligos etiologija gali būti labai ịvairi, visų epilepsijos priepuolių patogenezė yra tokia pati - savaiminė sinchronizuota staigi ir stipri galvos smegenų žievės neuronų grupès iškrova, kurios metu jaudinimo procesai išplinta smegenyse ir sutrikdo normalius neuronų grupių, užprogramuotų atlikti savo funkciją, ryšius [1]. Dažniausiai vaikų epilepsijos priepuoliai yra gerai kontroliuojami vaistais, tačiau kai kuriais atvejais, net ir pridejjus papildomus vaistus nuo epilepsijos (VNE), priepuoliai išlieka [2]. Tokia būklè, kai, paskyrus bent du gerai toleruojamus ir tinkamai parinktus bei vartojamus VNE, priepuoliai kartojasi, vadinama vaistams atsparia epilepsija (VAE) [3]. VAE pasitaiko 20-40 \% žmonių, sergančių epilepsija. Klinikiniuose tyrimuose nustatyta, kad šių pacientų mirtingumas yra didesnis, nei sergant vaistams jaut-

(C) Neurologijos seminarai, 2020. Open Access. This article is distributed under the terms of the Creative Commons Attribution 4.0 International License CC-BY 4.0 (http://creativecommons.org/licenses/by/4.0/), which permits unrestricted use, distribution, and reproduction in any medium, provided you give appropriate credit to the original author(s) and the source, provide a link to the Creative Commons license, and indicate if changes were made. 
ria epilepsija. Kai kurios mirtys yra susijusios su pagrindine epilepsijos priežastimi; kitos mirtys yra tiesiogiai susijusios su traukuliais - dèl epilepsijos būklès (status epilepticus) ar dèl su traukuliais susijusių nelaimingų atsitikimų. Staigi nepaaiškinama epilepsija sergančių pacientu mirtis (Sudden Unexpected Death in Epilepsy, SUDEP) yra 40 kartų dažnesnė tiems pacientams, kuriems kartojasi priepuoliai, nei tiems, kuriems priepuoliai yra sukontroliuoti [4]. Taigi gera priepuolių kontrolè sumažina mirtingumą ir mirštamumą nuo epilepsijos [5].

Literatūroje, kaip medikamentinio gydymo alternatyva, priklausomai nuo priepuolių tipo ir dažnio, pateikiami tokie gydymo metodai, kaip ketogeninè dieta, neurostimuliacija ir chirurginis epilepsijos gydymas [6]. Pastarasis yra laikomas veiksmingiausiu mažinant VAE priepuolius. Pasitelkiant ịvairius galvos smegenų struktūrinius ir funkcinius tyrimus: elektroencefalografiją (EEG), galvos smegenų magnetinio rezonanso tomografiją (MRT) ir pozitronų emisijos tomografiją (PET), siekiama nustatyti epilepsijos židinị ir funkcinę jị supančių galvos audinių svarbą, norint ivvertinti rezekcinės operacijos galimybes [2]. Tokią operaciją tikslinga atlikti, esant aiškiai lokalizuotam, lengvai prieinamam ir saugiai pašalinamam epileptogeniniam židiniui. Tačiau kai kuriais atvejais nustatyti židini yra sunku arba neįmanoma, nes iš jo sklindantys nerviniai impulsai yra labai greiti ir akimirksniu pereina ị kitą smegenų pusrutuli, sukeldami generalizuotus epilepsijos priepuolius. Tuomet svarstytinos paliatyvios procedūros, kurių tikslas sumažinti epilepsijos priepuolių sunkumą bei dažnị ir taip pagerinti vaiko gyvenimo kokybę. Klinikiniai tyrimai rodo, kad kaliozotomija (angl. corpus callosotomy, CC) yra ypač efektyvi esant atoniniams - staigaus kritimo, priepuoliams, tačiau gali būti veiksminga ir kitų tipų generalizuotiems priepuoliams sumažinti $[7,8]$. Literatūroje aprašomos šios procedūros ilgalaikès išeitys. Šiuo metu laikoma, kad CC yra efektyvus ir saugus vaikų epilepsijos gydymo metodas, esant sunkiai kontroliuojamai, vaistams atspariai epilepsijai, kai nèra aiškaus operabilaus epileptogeninio židinio.

\section{EPILEPSIJA. KLINIKINIS LIGOS APRAŠYMAS}

Epilepsija - tai lètinė centrinės nervų sistemos liga, kuri diagnozuojama, kai pasireiškia mažiausiai du neprovokuoti epilepsijos priepuoliai, kuriuos skiria daugiau nei 24 valandos, arba kai pasireiškia vienas neprovokuotas priepuolis, kai jo pasikartojimo rizika yra ne mažesnè nei $60 \%$, arba kai pakanka duomenu specifinio epilepsijos sindromo diagnozei. Epilepsija laikoma atsitraukusia, kai sergančiajam, kuris bent 5 metus nevartoja VNE, per pastaruosius 10 metų nebuvo epilepsijos priepuolio arba kai asmuo išauga iš rizikingo amžiaus tarpsnio, sirgdamas nuo amžiaus priklausoma epilepsija [9].

Vaikų epilepsija nuo suaugusiujų skiriasi klinikine priepuolių išraiška, ligos etiologija, atsaku į VNE ir unikaliais EEG modeliais. Šiuos skirtumus lemia kitokia epileptogenezė ir nervinių impulsų plitimas, kadangi vaikų smegenys, ypač naujagimių ir kūdikių, yra vis dar formavimosi stadijoje. Tokie smegenų ypatumai lemia dažnesnius priepuolius vaikų amžiuje, tačiau taip pat yra linkę dažniau išnykti savaime, vaikui augant, lyginant su suaugusiųu populiacija [10].

Epilepsijos priepuolị lemia paroksizminès nekontroliuojamos iškrovos neuronuose, kurie daugiausia yra išsidèstę galvos smegenų žievẻje. Tokios iškrovos dažniausiai yra savaiminės, grịžtamos ir trunka nuo kelių sekundžių iki kelių minučių [11]. Klinikinè priepuolių išraiška gali būti labai įvairi. Pagal priepuolių klinikinę išraišką ir trukmę, sąmonès būklę priepuolio metu, židiniškumo ir gretutinius požymius, įvykių seką ir požymių kaitą priepuolio metu ir atsižvelgiant į EEG tyrimo rezultatus, epilepsijos priepuoliai yra klasifikuojami pagal Tarptautinès lygos prieš epilepsiją (TLPE) praktinę priepuolių klasifikaciją (1 lentelè) [12]. Ši klasifikacija suskirsto visus epilepsijos priepuolius ị keturias pagrindines grupes: židininès pradžios, generalizuotos pradžios, nežinomos pradžios ir neklasifikuojami (kai nėra duomenų apie priepuoli).

Pagal nustatytą epilepsijos priepuolio (-ių) tipą epilepsija klasifikuojama į židininę, generalizuotą, kombinuotą generalizuotą ir židininę, arba nežinomos pradžios. Naujoji TLPE epilepsijos klasifikacija atsižvelgia ir ị epilepsijos etiologiją, kuri yra taip pat svarbi parenkant ligos gydymą. Pagal etiologiją epilepsija suskirstyta ị šešis pogrupius: struktūrinè, genetinè, infekcinè, metabolinè, imuninè ir nežinomos kilmès [13]. Kai kurios epilepsijos formos gali paveikti vaikus bet kokiame amžiuje, tačiau kitos yra būdingos tik tam tikro amžiaus vaikams.

\section{EPILEPSIJOS EPIDEMIOLOGIJA}

Epilepsija yra gana paplitusi pasaulyje liga. Jos dažnis siekia apie 5-6 sergančiuosius iš 1000 vaikų. Dažniausiai susergama pirmaisiais gyvenimo metais - iki 20 \% visų epilepsijos atvejų diagnozuojama jaunesniems nei $1 \mathrm{~m}$. amžiaus vaikams [14].

\section{EPILEPSIJOS GYDYMO METODAI}

Maždaug dviem trečdaliams sergančiųuc epilepsija priepuoliai yra gerai kontroliuojami VNE, tačiau kitai daliai vaistai yra tik iš dalies veiksmingi arba visai neveiksmingi. Epilepsijos priepuolių atsparumas vaistams dažnai išryškẻja jau medikamentinio gydymo pradžioje. Tokia būklè, kai, paskyrus bent du gerai toleruojamus ir tinkamai parinktus bei vartojamus VNE, priepuoliai kartojasi, vadinama vaistams atsparia epilepsija (VAE) [3]. VAE gydyti turi būti svarstomi papildomi nemedikamentiniai epilepsijos priepuolių gydymo metodai: chirurginis, klajoklio nervo stimuliacija (vagus nerve stimulation, VNS) ar ketogeninė dieta [2].

Chirurginis epilepsijos gydymas svarstomas vaikams, kuriems pasireiškia dažni epilepsijos priepuoliai, darantys neigiamą poveiki jų gyvenimui arba trukdantys jų pažinti- 
1 lentelè. TLPE 2017 m. epilepsijos priepuolių klasifikacijos išplèstinẻ versija

\begin{tabular}{|c|c|c|c|}
\hline \multicolumn{2}{|l|}{ Židininès pradžios } & \multirow[b]{2}{*}{\begin{tabular}{|l|} 
Generalizuotos pradžios \\
Motoriniai \\
toniniai-kloniniai \\
kloniniai \\
toniniai \\
miokloniniai \\
miokloniniai-toniniai-kloniniai \\
Nemotoriniai (absansai) \\
tipiniai \\
atipiniai \\
miokloniniai \\
akių vokų mioklonijos \\
\end{tabular}} & \multirow[b]{2}{*}{$\begin{array}{l}\text { Nežinomos pradžios } \\
\text { Motoriniai } \\
\text { toniniai-kloniniai } \\
\text { epilepsiniai spazmai } \\
\text { Nemotoriniai } \\
\text { veiklos sustojimas }\end{array}$} \\
\hline Be suvokimo sutrikimo & Su suvokimo sutrikimu & & \\
\hline $\begin{array}{l}\text { Motorinės pradžios } \\
\text { automatizmai } \\
\text { atoniniai }{ }^{1} \\
\text { kloniniai } \\
\text { epilepsiniai spazmai }{ }^{1} \\
\text { hiperkinetiniai } \\
\text { miokloniniai } \\
\text { toniniai }\end{array}$ & & & Neklasifikuojami $^{2}$ \\
\hline $\begin{array}{l}\text { Nemotorinės pradžios } \\
\text { autonominiai } \\
\text { veiklos sustojimas } \\
\text { kognityviniai } \\
\text { emociniai } \\
\text { sensoriniai }\end{array}$ & & & \\
\hline Židininiai, išplintantys ị a & us toninius-kloninius traukulius & & \\
\hline
\end{tabular}

${ }^{1}$ Suvokimo lygis dažniausiai nenurodomas. ${ }^{2}$ Priepuolis gali būti neklasifikuojamas dèl nepakankamos informacijos ar negalejjimo priskirti tipo kitoms kategorijoms.

nei ir psichosocialinei raidai [14]. Ypač sunkiai kontroliuojami vaistais atoniniai priepuoliai, literatūroje dažnai vadinami anglišku terminu drop attacks (kritimo priepuoliai). Jie pasižymi staigiu raumenų tonuso sumažejjimu tam tikroje vienoje (pvz., galvos, kaklo ar galūnių) arba visose raumenų grupèse (generalizuoti) ir pacientas staigiai nukrenta. Šie priepuoliai yra nenuspejjami ir gali sukelti rimtų traumų kritimo metu, dẻl ko labai sutrikdo pacientų ir jų šeimų kasdienybę. Todèl, esant šio tipo priepuoliams, dažnai reikalingas chirurginis gydymas [15]. Taip pat dažnai pasikartojantys priepuoliai, ypač jauname amžiuje, daro didelę neigiamą įtaką aukštesniųjų žievès funkcijų vystymuisi - kalbai, pažintinèms funkcijoms, mokymuisi, elgesiui, miegui. Operacija tuo yra sėkmingesnè, kuo ankstesniame amžiuje ji atliekama, kadangi besivystančios smegenys yra plastiškos, o tai palengvina pooperacinị funkcinị smegenų atsigavimą ir persitvarkymą [16]. Chirurginis gydymas yra vienas veiksmingiausių, gydant VAE [5].

Operacinis gydymas parenkamas kiekvienam vaikui individualiai, atsižvelgiant ị priepuolių pobūdị ir išsamaus ištyrimo rezultatus. Visi pacientai ištiriami atliekant standartines EEG, ilgalaiki EEG monitoravimą miego ir (ar) būdravimo metu (esant reikalui, EEG su miego deprivacija ar specifiniais mėginiais), vaizdo EEG monitoravimą - tai padeda nustatyti epilepsijos židinị. Daugeliu atvejų neinvaziniai tyrimai leidžia lokalizuoti epileptogeninị židinị ir nustatyti epilepsijos formą [17].
Epilepsijos operacinị gydymą galima suskirstyti ị mažiau invazyvias procedūras, tokias kaip VNS, ir ị invazyvias - epilepsinio židinio rezekciją, lobektomiją, kaliozotomiją, hemisferektomiją ir daugybinę subpialinę transekciją [18]. Didelę ịtaką, parenkant operacinį gydymą, turi priepuolių tipas ir epilepsinio aktyvumo lokalizacija smegenyse [2]. Idealaus chirurginio gydymo tikslas yra pašalinti epileptogeninị židini, o tam reikia nustatyti jị ir įvertinti defekto pavojų po operacijos. Tais atvejais, kai rezekcija negalima arba ją atlikti yra per daug rizikinga, galima pasitelkti paliatyvias chirurginio gydymo priemones, kuriomis siekiama nutraukti priepuolių plitimą - antrinę priepuolių generalizaciją [17].

\section{KALIOZOTOMIJA}

\section{Istorija}

Pirmają kaliozotomiją 1940 m. atliko tuometinis Amerikos neurochirurgų asociacijos prezidentas William P. van Wagenen. Bandydamas rasti naujus epilepsijos gydymo metodus, chirurgas atliko daugelị klinikinių tyrimų ir publikavo jų rezultatus, tarp jų ir išeitis po didžiosios smegenų jungties perpjovimo. Šie tyrimai paskatino ir kitus neurochirurgus tirti kaliozotomijos efektyvumą, gydant epilepsiją. 1981 m. Roger W. Sperry moksliniai tyrimai apie 
„smegenų perskyrimą“ („split-brain“) laimėjo Nobelio premiją. R. W. Sperry tyrė pacientus, kuriems buvo atlikta kaliozotomija, ir išsamiai aprašè pacientų su „atskirtomis smegenimis“ elgesio savybes [19].

Kaliozotomijos technika patobulejo nuo pirmojo jos atlikimo ir šiandien P. W. van Wagenen atrasta operacija yra atliekama visame pasaulyje, gydant epilepsijos priepuolius.

\section{Veiksmingumo teorija}

Po 1940 m. publikuoto P. W. van Wagenen ir R. Herren klinikinio tyrimo, atsirado teorija, kad visi generalizuoti epilepsijos priepuoliai pačioje priepuolio pradžioje kyla iš židinio, esančio viename galvos smegenų pusrutulyje, ir tik po to plinta plačiai ị kitas smegenų dalis, taip pat ir kitą pusrutuli [20]. Apie 70-80\% abiejų pusrutulių žievès jungiasi per corpus callosum. Ši neuronų jungtis leidžia pusrutuliams integruotis ị vienas kito veiklą ir darniai sąveikauti, taip pat yra ir žievès aktyvumo moduliatorius - gali tiek sužadinti, tiek ir slopinti smegenų žievès veiklą [21]. Didžioji smegenų jungtis yra svarbiausia jungtis nerviniam impulsui plisti tarp abiejų smegenų pusrutulių, todėl jos perpjovimas sutrikdo nervinių impulsų plitimą, taip sustabdydamas epilepsijos priepuolio generalizaciją [10]. Jungtis yra sudaryta iš priekinių neuronų pluoštų, jungiančių frontalinę pusrutulių žievę, ir iš užpakalinių, jungiančių užpakalines žievès struktūras. Pagal šią topografinę padètị operacijos metu gali būti perpjaunama nuo pusès iki keturių penktadalių corpus callosum pluoštų [22].

\section{Atrankos kriterijai}

Oficialiai priimtų absoliučių indikacijų kaliozotomijai nèra, kiekvienam pacientui šis gydymas parenkamas individualiai, atsižvelgiant ị paciento ligą ir priepuolių sukeliamus sunkumus [10]. Literatūroje minimos tokios indikacijos, kaip besikartojantys atoniniai priepuoliai, Westo (West) arba Lenokso-Gasto (Lennox-Gastaut) sindromas, pasikartojantys epilepsinès būklès epizodai, židininiai su suvokimo sutrikimu, generalizuoti toniniai-kloniniai ir absansų priepuoliai. Dažniausiai CC yra atliekama pacientams, sergantiems VAE, kuriems pasireiškia generalizuotos pradžios ar židiniai su antriniu išplitimu priepuoliais ir kurie nèra tinkami rezekcinėms operacijoms, arba pacientams su epilepsijos židiniu priekinëje galvos smegenų skiltyje / dalyje, kurio neịmanoma tiksliai lokalizuoti ar pašalinti [8].

\section{Priešoperacinis ištyrimas}

Pacientams, kuriems planuojama atlikti CC, atliekamas išsamus priešoperacinis ištyrimas. Pirmiausia patvirtinama VAE diagnozè - priepuolių kartojimasis reguliariai vartojant bent du gerai toleruojamus ir tinkamai parinktus VNE. Tuomet įsitikinama, kad galvos smegenų tyrimai nenurodo vieno ar kelių aiškių epileptogeninių židinių, kuriuos būtų galima saugiai pašalinti rezekcinès operacijos metu.
Taip pat pacientui ir jo šeimai išaiškinama, kad CC yra paliatyvi operacija, ir detaliai aptariami paciento lūkesčiai bei galimos išeitys po operacijos [23]. Paciento detalus ivertinimas, ar tinka chirurginiam gydymui, yra reikalingas, siekiant kuo labiau sumažinti pooperacinị ir operacinị mirštamumą ir kalbos bei kitų funkcinès žievès zonų pažeidimo galimybes operacijos metu. Toliau aptariamas standartinis kaliozotomijos priešoperacinis įvertinimas [24].

\section{Klinikinis įvertinimas}

Surenkama visa medicininè anamnezè, įskaitant priepuolių tipą (-us) ir dažnį, VNE vartojimo anamnezè (nustatant, ar pagristai diagnozuota VAE), ịvertinama neurologinè ir somatinè būklè, kasdienè vaiko veikla, gyvenimo kokybė ir raidos, nuotaikos bei elgesio ypatumai.

\section{Neurofiziologinis testavimas}

İvertinami verbalinio ir neverbalinio intelekto, mokymosi ir atminties sutrikimai, siekiant palyginti su pooperaciniais rezultatais ir įvertinti gydymo naudos bei galimos žalos santyki [25].

\section{Rutininè ir vaizdo EEG}

Patvirtinami ar nustatomi priepuolių tipai ir lokalizuojami epilepsijos židiniai, sergant židinine epilepsija, ir įvertinamos rezekcinès operacijos galimybès. Nustatoma pirminè priepuolio generalizacija, sergant generalizuota epilepsija [26].

\section{Galvos smegenų MRT}

İvertinama struktūriniai galvos smegenų pažeidimai ir didžiosios smegenų jungties anatomija [8].

\section{Pozitronų emisijos tomografija (PET)}

Šis tyrimas, vertinamas kartu su galvos smegenų MRT rezultatais, padidina priešoperacinio ištyrimo kokybę, ypač pacientams, kuriems buvo neaiškūs MRT rezultatai. Tokiems pacientams PET gali nurodyti hipometabolines zonas galvos smegenyse, kurios dažniausiai žymi epilepsijos priepuolio pradžios vietą galvos smegenų žievėje [24].

\section{Operacija}

Didžioji smegenų jungtis operacijos metu gali būti perpjaunama iš dalies arba pilnai (totaliai). Operacijos variantai gali būti: pilna (totalinè) kaliozotomija, dviejų priekinių trečdalių kaliozotomija su ar be hipokampo jungties perpjovimo ir dviejų etapų operacija (pirmosios operacijos metu paliekamos kai kurios neuronų jungtys, tačiau, jei pagerejjimo nėra ar jis yra dalinis, likusios jungtys nupjaunamos antros operacijos metu). Šiuo metu dažniausiai atliekama dviejų priekinių trečdalių kaliozotomija [23, 27]. 


\section{KLINIKINIŲ ATVEJŲ APRAŠYMAI}

\section{1 atvejis. 9 metų mergaitė}

\section{Gyvenimo ir ligos anamnezè}

Paciente gimė iš III (III) normalaus něštumo ir gimdymo. Gimė laiku, natūraliais takais. İvertinta 9 balais pagal Apgar skalę.

4 mèn. amžiuje pastebèta, kad mergaitė nenaudoja kairès rankos - ją laiko sulenktą, menkai judina. 6 mẻn. amžiuje atliktas galvos KT tyrimas ir rasti pakitimai dešiniojo galvos smegenų pusrutulio centro parietalinèje srityje su kalcinatais, nustatyta igimta galvos smegenų dešiniojo pusrutulio formavimosi yda. Diagnozuotas cerebrinis paralyžius: spazminè hemiplegija kairèje. Psichomotorikos ir kalbos raida atsiliko: vaikščioti pradejjo nuo 2 m., kairiosios galūnès buvo spazmiškos ir riboto judrumo, vẻlavo kalbos ir pažintinė raida, $3 \mathrm{~m}$. amžiaus gebejjo kalbėti tik pavieniais garsažodžiais, lankè specialujji vaikų darželį.

Pacientè, būdama 3,5 m., susirgo vẻjaraupiais ir po ligos prasidèjo priepuoliai, kurių metu atlošdavo galvą, užversdavo akis. Jie kartodavosi apie 5 kartus per dieną.

Šeimos anamnezė: šeimoje segančiųjų epilepsija, raidos sutrikimais nebuvo.

\section{Ištyrimas, gydymas ir ligos eiga}

Miego EEG: fiziologinių miego fenomenų neužregistruota. Registruotas beveik pastovus, labai intensyvus, polimorfiškas multifokalinis epilepsiforminis aktyvumas (tiek smailios bangos, tiek aštrios-lètos bangos kompleksai), kiek intensyvesnis dešiniajame pusrutulyje. Diagnozuota struktūrinė generalizuota epilepsija, pradètas gydymas valproatu „Depakine“.

Praejjus apie 2 sav. nuo gydymo pradžios, keitėsi priepuolių pobūdis, priepuolio metu atsirado abipusiai galūnių ir veido raumenų kloniniai trūkčiojimai, žvilgsnis būdavo fiksuotas, nukrypęs į šoną arba ị viršų, jų metu mergaitè suglebdavo (jei stovėdavo - nukrisdavo, jei sėdėdavo - nusvirdavo ị priekį ar atgal). Priepuoliai ilgẻjo iki 20-30 sek., dažnėjo iki 6-7 priepuolių per valandą viso būdravimo metu. Po priepuolio mergaitė iš karto atsigaudavo ir tęsdavo prieš tai buvusią veiklą. Tarp priepuolių mergaitẻ būdavo gana aktyvi, smalsi, žaidè sèdėdama, nes vienai vaikščioti tapo nesaugu. (Priepuoliai vertinti kaip galimai židininiai su greita generalizacija.)

Galvos smegenų MRT: galvos smegenų pusrutulių asimetrija: dešinysis pusrutulis - mažesnis, dešinejje frontotemporalinėje (FT) srityje smegenų žievė sustorèjusi, redukuoti / minimalūs vingiai - pachi- mikrogirijos vaizdas. Galvos smegenų baltojoje medžiagoje periventrikuliariai difuziniai glioziniai pakitimai, vietomis siekiantys subkortikalinị lygį, ryškesni kairejje. Vidurio linija su skilveliais reliatyviai pasislinkusi į dešinę, dèl galvos smegenų pusrutulių asimetrijos. Šoniniai skilveliai - asimetriški (d > k), praplèsti, HI $\sim 65 \mathrm{~mm}$, III skilvelis $\sim 6 \mathrm{~mm}$, IV skilvelis vidurio linijoje. Smulkių kalcinatų požymiai ties šoninių skilvelių vidinėmis sienelèmis. Subarachnoidiniai tarpai konveksitaliai nežymiai praplèsti (iki $3 \mathrm{~mm}$ ). Intrakraniji- nès kraujagyslès - be patologinių pokyčių. Išvados: galvos smegenų pusrutulių asimetrija $(\mathrm{d}<\mathrm{k})$, galvos smegenų displazijos (pachi- mikrogirijos požymiai) vaizdas dešinėje FT skiltyse - pakitimai būdingi lizencefalijai. Abipusiai glioziniai baltosios medžiagos-požievio pakitimai (vyraujantys kairejje), smulkių kalcinatu požymiai ties šoninių skilvelių vidinėmis sienelèmis. Vidinė hidrocefalija.

Būdravimo ir miego EEG: snūduriuojant registruoti trumpi normalaus teta, alfa ritmo epizodai ir lokalus epilepsiforminis aktyvumas: pikų iškrovos dešinèje T6-T4-C4-P4 srityse. Užmigus ir miegui gilejant, neregistruota miego stadijų, išryškèja pastovus smaili-lèta banga abipusiai sinchronizuotas generalizuotų smailių bangų aktyvumas, iškrovos gausejja iki $100 \%$ - ESES (Electrical Status Epilepticus in Sleep), kuris protarpiais būna kiek asimetriškas - ryškesnis dešinėje.

Atlikus diagnostinị vaikų raidos vertinimo testą (Diagnostic Inventory for Screening Children, DISC), nustatytas vidutinio sunkumo raidos sutrikimas visose raidos srityse: smulkioji motorika - 27 mèn. (59\%), kalbos supratimas - 20 mèn. (43\%), ekspresinė kalba - 15 mèn. (33\%), stambioji motorika - 18 mèn. (39\%), girdimasis dėmesys ir atmintis - 20 mèn. (43\%), regimasis dèmesys ir atmintis - 25 mèn. (54\%), savarankiškumas - 20 mèn. (43\%), socialinio bendravimo ịgūdžiai - 15 mèn. (33\%).

Klinikinè diagnozè: struktūrinè generalizuota epilepsija G40.41. Cerebrinis paralyžius: spazminė hemiplegija kairejje G80.02. Igimta galvos smegenų formavimosi yda: dešiniojo pusrutulio lisencefalija (pachi- mikrogirija), abipusiai glioziniai baltosios medžiagos pakitimai, kalcinatai, vidinè hidrocefalija Q04.8. Specifinis mišrus raidos sutrikimas F83.

Gydymas: pasiekta maksimali valproato dozè, bet mergaitè tapo mieguista, irzli, o priepuoliai neretejo. Dozė sumažinta, taikytas gydymas metilprednizolo pulsais ị veną - be efekto, pridètas klonazepamas - be efekto, tapo mieguista, irzli.

Būdravimo ir miego EEG: prieš užmiegant registruojamas kiek sulètintas pagrindinis smegenų žievès bioelektrinis aktyvumas erdvinio išsidèstymo. Lokalus epilepsiforminis aktyvumas: pikų iškrovos dešinejje. Užmigus ir miegui gilèjant, išryškejja pastovus smaili-lèta banga abipusiai sinchronizuotas aktyvumas, iškrovos gausėja iki $100 \%$ ESES. Fiziologiniai miego elementai neregistruojami. Vaizdo EEG: registruoti 6 priepuoliai, kai staiga pradeda ritmiškai linkčioti galva, ritmiškai kilsčioti rankos, mirkčioti akys, kūnas svyra ị priekį arba atgal, sąmonè priepuolio metu kinta - veikla sustoja laikinai, nes mergaitė bando tęsti pradètą veiklą. Trukmè - iki 10-20 sek. EEG tuo metu registruojamos abipusiai sinchronizuotos smailiu bangu iškrovos, galimai kylančios dešinèje hemisferoje.

Diagnozuota: struktūrinė židininė gydymui atspari (sunkiai gydoma) epilepsija.

Tolimesnis gydymas: valproatai pakeisti levetiraceta$\mathrm{mu}$, po to pridètas klobazamas, topiramatas - pradžioje priepuolių sumažèjo, išbandytas gydymas diakarbu, nitrazepamu - be efekto, pridètas etosukcimidas - priepuoliu gerokai sumažèjo, vèliau - sultiamas - be žymesnio efek- 
to, išbandytas karbamazepinas - ji vartojant priepuoliai dažnėjo, pridėtas vigabatrinas - be aiškaus efekto. Ivedus naują vaistą nuo epilepsijos, ypač topiramatą ir etosukcimidą, priepuoliai kartais suretėdavo iki $10-20$ per dieną, bet ilgainiui vèl padažnėdavo iki kelių per valandą.

Po pusmečio neefektyvaus medikamentinio gydymo, pradèta svarstyti paliatyviosios chirurgijos - kaliozotomijos galimybė; mama supažindinta su operacijos galimu efektyvumu ir komplikacijomis, tačiau vis nesiryžo, laukè, kol bus išbandyti potencialiai efektyvūs vaistai nuo epilepsijos.

Po 1 metų 6 mèn. medikamentinio gydymo ( 1 metų 7 mèn. nuo priepuolių atsiradimo) nuspręsta taikyti chirurginį epilepsijos gydymą - atlikti kaliozotomiją.

$5 \mathrm{~m} .3 \mathrm{mèn}$. mergaitei, po $1 \mathrm{~m} .8 \mathrm{men}$. neefektyvaus medikamentinio gydymo, atlikta neurochirurginé operacija kraniotomija ir pilna kaliozotomija (Craniotomia parasagittalis frontalis et parietalis dex. Callosotomia). Pooperacinių komplikacijų nebuvo. Po operacijos priepuoliai visiškai išnyko. Operacijos metu mergaitė vartojo 4 vaistus nuo epilepsijos: levetiracetamą, topiramatą, etosukcimidą ir sultiamą. Jau prieš operaciją pradètas topiromato mažinimas tęstas.

1 mèn. po operacijos EEG: kiek sulètintas pagrindinis smegenų žievès bioelektrinis aktyvumas, sutrikdomas epilepsijos iškrovų. Vertinant dinamikoje, daug mažesnè iškrovų generalizacija.

6 mèn. po operacijos

Būdravimo ir miego EEG: užmigus miego elementų nèra. Pastovus epilepsiforminis aktyvumas visoje dešinėje hemisferoje - smailių bangų ir pikų iškrovos.

Galvos MRT: būklè po kaliozotomijos. Dešiniojo smegenų pusrutulio lizencefalijai būdingi pakitimai. Sutrikusios mielinizacijos plotai peri- supraventrikuliariai abipus.

7 mèn. po operacijos tęstas VNE palaipsnis mažinimas.

3 metai po operacijos - visiškai nutrauktas medikamentinis gydymas VNE.

3,5 m. po operacijos EEG: registruojamas kiek sulėtintas pagrindinis smegenų žievès bioelektrinis aktyvumas. Židininis epilepsiforminis aktyvumas: asinchroniškos, gausios pikų ir smailių aštrių bangų iškrovos, vyrauja kairèje hemisferoje.

Išeitis. Praejus 4 metams po kaliozotomijos, epilepsijos priepuoliai nesikartoja, pagerejo mergaitès raida ir mobilumas - vaikšto pati, kalba daugiausia sava kalba, moka ir žodžių junginių, žodyne bent pora šimtų žodžių, tačiau dažniausiai atsako pavieniais žodžiais, gereja pažintiné raida, labai pagerejo vaiko ir šeimos gyvenimo kokybė.

\section{2 atvejis. 11 metu berniukas}

\section{Gyvenimo ir ligos anamnezè}

Pacientas gimè laiku iš II (II) normalaus nèštumo ir gimdymo. Gimus diagnozuota 21 chromosomos trisomija (Dauno sindromas). Raida atsilieka nuo gimimo.

6 mèn. amžiuje atsirado pavieniai miokloniniai priepuoliai su galvos linktelèjimu žemyn, fiksuotu žvilgsniu ir serijiniai ekstenziniai infantiliniai spazmai, kurie kartojosi kasdien.

Šeimos anamnezė: šeimoje sergančiųjų epilepsija, raidos sutrikimais nebuvo.

\section{Ištyrimas, gydymas ir ligos eiga:}

EEG: registruotas multifokalinis epilepsinis aktyvumas, hipsaritmijos epizodai. Diagnozuota genetinè generalizuota epilepsija (G40.40) ir pradėtas gydymas valproatu (VPA). Priepuoliams nesiliovus, pradèta pulsterapija metilprednizolonu i vena.

Praejjus apie 6 mėn. nuo gydymo pradžios, pilna priepuolių kontrolè nebuvo pasiekta; nutrauktas metilprednizolonas, tęstas gydymas VPA, pridètas lamotriginas, vèliau - topiramatas. Palaipsniui didinat dozes, infantiliniai spazmai išnyko, tačiau pradejjo kartotis židininio pobūdžio priepuoliai iki kelių kartų per dieną. İ gydymo planą įvestas nitrazepamas nakčiai ir pakartotinai skirta metilprednizolono pulsterapija po $250 \mathrm{mg}$ ị veną, 3 dienas, kas mènesi 3 mèn., vèliau skirta vienkartinè metilprednizolono $250 \mathrm{mg}$ dozè ị veną kas mẻn.

Praejus 2 mèn. po gydymo korekcijos, pacientas pateko i Intensyviosios terapijos skyrių dèl išsekimo ir skysčiu trūkumo, išryškejjus šalutiniam VNE poveikiui (bėrimai, skysčių trūkumas, apetito stoka). Gydymas lamotriginu ir topiramatu nutrauktas.

Galvos smegenų KT: be patologinių pakitimų

Po pusès metų, gydymo fone kartojosi toniniai-kloniniai priepuoliai ir infantiliniai spazmai, kurių dinamikoje nemažèjo. Pradètas gydymas vigabatrinu. Berniukas tapo žvalesnis, aktyvesnis, labiau domėjosi aplinka, pradejjo stotis, imti žaislą i rankas, priepuoliai tapo retesni, pakito jų pobūdis: vaikas ịsitempdavo ir palinkdavo ì prieki, žvilgsnis buvo fiksuotas, sutrūkčiodavo rankytès, trukmè - 1-2 sek., dažnis - 1-3 kartų per dieną, daugiau ryte. Gydymui pridėtas levetiracetamas.

Miego EEG: užmigus miego elementai neregistruoti. Intermituojantys epilepsiniai iškrūviai $-1,5-2 \mathrm{~Hz}$, būdingi Lenokso-Gasto sindromui, epilepsinei encefalopatijai. Miegui gilèjant, pereina į iškrūvio-slopinimo epizodus.

Klinikinè diagnozè: genetinè generalizuota ir židininè epilepsija: polimorfiniai priepuoliai, sunkiai gydoma (vaistams atspari) forma - Lenokso-Gasto sindromas G40.41. Specifinis mišrus raidos sutrikimas F83. 21 chromosomos trisomija Q 90.9. Elgesio sutrikimas F91.8.

Gydymas: vigabatrinas, levetiracetamas, VPA ir diazepamas (rektaliai), esant reikalui.

Praejjus $1 \mathrm{~m}$., mama pastebejo, kad vaikas smaugiasi būdamas vežimėlyje, lovytėje. Konsultuotas psichologo, vaikų psichiatro, diagnozuoti pseudoepilepsiniai savistimuliacijos paroksizmai (F98.4), skirtas medikamentinis gydymas neuroleptiku chlorprotiksenu („Truxal“), dèl apsaugos turèjo dèvèti specialią liemenę su paaukštinta apykakle. Išliko miokloniniai epilepsijos priepuoliai - berniukas ịsitempdavo, išskèsdavo rankas, sustingdavo. Priepuolio trukmè - iki 30 sek.

Galvos smegenų MRT: retrocerebeliariai matyti cista apie $38 \times 41 \times 17 \mathrm{~mm}$ dydžio. 
Miego EEG: multifokalinis lokalus epilepsiforminis aktyvumas, vyraujantis abipus TP srityse su greita generalizacija: labai gausūs smailių bangų, pikų generalizuoti ritminiai iškrūviai su iškrūvio-slopinimo epizodais. Pakitimai būdingi epilepsinei encefalopatijai.

Pridètas gydymas fenobarbitaliu.

Vèliau keitèsi priepuolių pobūdis - po nubudimo atsirado staigaus kritimo priepuoliai su apsunkintu kvèpavimu ir akių derivacija ị kairę, jų metu ị aplinką nereagavo, priepuolio trukmè buvo 1-5 min.

EEG: intermituojantis lokalus epilepsinis aktyvumas $\mathrm{F}$ abipusiai kompleksu smaili-lèta banga, kuris pereina ị generalizuotą epilepsinį aktyvumą 1,5-2 Hz, ir iškrūvio-slopinimo epizodas. Pakitimai yra būdingi epilepsinei encefalopatijai.

Tolimesnis gydymas: skirtas adrenokortikotropinis hormonas; atsiradus ūminiam bronchitui, nutrauktas. Pridèta diakarbo, deksametazono, okskarbazepino.

Gydymo fone priepuoliai trumpam išnyko, bet vèliau vèl kasdien kartojosi pavieniai paroksizmai su toniniu viso kūno ịsitempimu, rankų sulenkimu per alkūnes, pasišlapinimu ar pasituštinimu, trukmé - iki 5 min. Išliko smaugimosi, oro „sulaikymo“, sustingimo epizodai būdraujant. Po ilgesnių, stipriau išreikštų smaugimosi epizodų, būdavo priepuoliai su akių derivacija ị viršų, įsitempimu, rankų skèstelejjimu, lūpų čepsẻjimu ir verkimu priepuolio pabaigoje. Taip pat buvo sutrikęs miegas (nemiegodavo iki 2 val. nakties), greičiau pavargdavo, mažiau domėjosi aplinka, dažnai čiulpdavo nykštị.

Pradèta svarstyti paliatyviosios chirurgijos - kaliozotomijos, galimybė. Mama supažindinta su operacijos galimu efektyvumu ir komplikacijomis, laukta, kol apsispręs.

Po ilgalaikio neefektyvaus medikamentinio gydymo nuspręsta taikyti chirurginį epilepsijos gydymą - atlikti kaliozotomiją.

$10 \mathrm{~m}$. berniukui atlikta neurochirurginè operacija kraniotomija ir pilna (totalinè) kaliozotomija (Craniotomia parasagittalis frontoparietalis dex. Callosotomia totalis). Pooperacinių komplikacijų nebuvo. Po operacijos priepuoliai nesikartojo. Pacientas tapo žvalesnis, aktyvesnis, gyvesnès emocinės reakcijos. Pats paejo kelis žingsnius. Operacijos metu berniukas vartojo valproatą ir levetiracetamą. Medikamentinis gydymas tęstas.

1 mèn. po operacijos galvos smegenų KT: būklè po neurochirurginès operacijos; pooperacinè pneumocefalija; pakraujavimo požymių nesimato.

7 mèn. po operacijos miego EEG: daugiažidininis epilepsiforminis aktyvumas; polimorfinès pikų, smailių bangų iškrovos kairèje ir dešinejje hemisferoje asinchroniškai, centro-fronto-temporaliai. Miegui gilejjant, išryškejja iškrovos-slopinimo fenomenas, 1-2 Hz smaili-lèta banga kompleksų kairejje arba dešinėje hemisferoje išplitusios iškrovos.

Išeitis: Praẻjus 7 mèn. po operacijos, epilepsijos priepuoliai nesikartojo. Berniukas pasidaré žvalesnis, aktyvesnis, labiau doméjosi aplinka ir pradejjo savarankiškai vaikščioti. Buvo nuspręsta mažinti VPA dozę, tačiau, ją sumažinus, prasidejo epilepsijos priepuoliai naktimis (apie 20 per nakti), kurių metu berniukas įsitempdavo, trūkčiodavo galūnès, sutrikdavo kvėpavimas; priepuolis trukdavo iki 1 min. Ryte berniukas būdavo vangus, be nuotaikos, išnyko po operacijos atsiradęs progresas - nustojo savarankiškai vaikščioti. Nuspręsta vèl padidinti VPA dozę iki buvusios, tačiau priepuoliai išliko. Smaugimosi, oro „sulaikymo“, sustingimo, nykščio čiulpimo epizodai būdraujant taip pat išliko. Tęstas gydymas VPA ir LEV, berniukas juos toleruoja gerai.

$1 \mathrm{~m}$. po operacijos EEG: fiziologiniai miego elementai - miego verpstès, V-bangos, K-kompleksai, delta bangos - iprastinio išsidèstymo, be pastovesnès asimetrijos. Intermituojantis lokalus epilepsinis aktyvumas Fp1, T9, F4 su abipusiu išplitimu.

Praejjus $1 \mathrm{~m}$. po operacijos, epilepsijos priepuoliai išlieka. Berniukas stebimas toliau. Tęsiamas medikamentinis ir reabilitacinis gydymas.

\section{APTARIMAS}

Kaliozotomija klinikinejje praktikoje taikoma daugiau nei 70 metų. Ši operacija laikoma sėkmingu paliatyviu chirurginiu VAE gydymu, siekiant sumažinti ar panaikinti epilepsijos priepuolius, kai rezekcinès operacijos yra negalimos. CC efektyvumas ir santykinai mažas komplikacijų ir mirštamumo lygis atsispindi per pastaruosius 70 metų atliktų klinikinių tyrimų rezultatuose, ịvairiose sisteminèse apžvalgose ir naujausioje literatūroje [8].

Teigiamos išeitys po CC yra priepuolių dažnio ir sunkumo sumažèjimas, vaiko savarankiškai atliekamų kasdienių veiklų ir galimybių padidejjimas bei visos vaiko šeimos gyvenimo kokybės pagerejimas. Kaip ir kiekviena invazinè procedūra, taip ir CC gali turèti neigiamų pasekmių - operacijos komplikacijų, tokių kaip neurologinių funkcijų deficitai, galvos smegenų pusrutulių atjungimo sindromas (disconnection syndrome), atminties sutrikimai, kasdienių funkcijų pablogèjimas ir kt.

Toliau pateikiama kaliozotomijos operacijos rezultatų ir komplikacijų literatūros apžvalga.

\section{Priepuolių dažnio sumažèjimas}

Naujausių klinikinių tyrimų rezultatai apžvelgiami 2 lentelèje. Pateiktose studijose (stebėjimo laikotarpis po operacijos - ne mažesnis nei 12 mèn.) visiškas priepuolių išnykimas po kaliozotomijos siekia nuo 6 iki $35 \%$, o jų dažnio sumažėjimas $\geq 50 \%$ - nuo 50 iki $88 \%$ [28-34]. CC efektyvumas koreliuoja su priepuolių tipu ir epilepsijos sindromu, vaiko amžiumi priepuolių pradžios ir operacijos metu, epilepsijos trukme ir radiniais galvos smegenų MRT prieš operaciją.

Didžiausia imtis, 55 vaikai, pristatyta $2017 \mathrm{~m}$. publikuotame D. Graham ir kt. retrospektyviniame tyrime [33]. Stebejjimo trukmės mediana po operacijos - 36 mèn. Šiame tyrime nustatyta, kad, jei priepuoliai nepasikartoja per 12 mèn. po operacijos, tikètina, kad jie ir nepasikartos vèlesniu laikotarpiu, ir pacientams, kuriems pasireiškè ma- 
2 lentelè. Epilepsijos priepuolių sumažèjimas po kaliozotomijos [28-34]

\begin{tabular}{|c|c|c|c|c|c|c|c|}
\hline \multirow[b]{2}{*}{$\begin{array}{l}\text { Priepuolių } \\
\text { išnykimas ar } \\
\text { dažnio } \\
\text { sumažejjimas }\end{array}$} & \multicolumn{7}{|c|}{ Autorius, metai ir imtis } \\
\hline & $\begin{array}{l}\text { Liang ir kt.; } \\
2015 \mathrm{~m} \text {. } \\
\mathrm{N}=14 \text {, vaikai } \\
\text { ir suaugusieji }\end{array}$ & \begin{tabular}{|l|} 
Iwasaki ir kt.; \\
$2016 \mathrm{~m}$. \\
$\mathrm{N}=26$, vaikai \\
ir suaugusieji
\end{tabular} & $\begin{array}{l}\text { Luat ir kt.; } \\
2017 \mathrm{~m} . \\
\mathrm{N}=20 \text {, vaikai }\end{array}$ & $\begin{array}{l}\text { Graham ir kt.; } \\
2017 \mathrm{~m} \text {. } \\
\mathrm{N}=55 \text {, vaikai }\end{array}$ & $\begin{array}{l}\text { Hong ir kt.; } \\
2018 \mathrm{~m} . \\
\mathrm{N}=10, \text { vaikai } \\
\text { ir suaugusieji }\end{array}$ & $\begin{array}{l}\text { Itamura ir kt; } \\
2019 \mathrm{~m} . \\
\mathrm{N}=25, \text { vaikai }\end{array}$ & $\begin{array}{l}\text { Lien ir kt.; } \\
2020 \mathrm{~m} . \\
\mathrm{N}=16 \text {, vaikai }\end{array}$ \\
\hline Priepuoliai išnyko & $22,2 \%$ & $19,2 \%$ & $35 \%$ & $\mathrm{~N}^{3}$ & $0 \%$ & $20 \%$ & $6,3 \%$ \\
\hline$\geq 50 \%^{1}$ & $32,8 \%$ & $38,5 \%$ & $50 \%$ & $47 \%$ & $50 \%$ & $20 \%$ & $81,2 \%$ \\
\hline$<50 \%^{2}$ & $45 \%$ & $42,3 \%$ & $15 \%$ & $53 \%$ & $50 \%$ & $60 \%$ & $12,5 \%$ \\
\hline
\end{tabular}

${ }^{1}$ Priepuolių dažnis sumažejo $\geq 50 \%$. ${ }^{2}$ Priepuolių dažnis sumažèjo $<50 \%$, nepakito arba padidèjo. ${ }^{3}$ Nèra duomenų

žiau nei trys skirtingi priepuolių tipai prieš operaciją, po operacijos stebimi geresni rezultatai. Paskutinio stebėjimo metu 26 pacientams iš 55 (47\%) priepuoliai buvo reti arba nebesikartojo. Tačiau tiems, kuriems priepuoliai po operacijos kartojosi, jie buvo lengvesni, pacientai patyrė mažiau susižalojimų jų metu, taigi ir jiems operacija turèjo teigiamą itaką, nors rezultatuose to ir nematome [33].

$2018 \mathrm{~m}$. publikuotoje A. Y. Chan ir kt. 58 studijų metaanalizèje, kurioje atsispindi 1742 pacientų, gydytų CC, išeitys, nurodoma, kad visiškas epilepsijos priepuolių išnykimas po CC siekia nuo 18,8 iki 55,3 \% (stebejjimo laikotarpis po operacijos - ne mažesnis nei 12 mèn.) ir geriausi rezultatai buvo gaunami esant infantiliniams spazmams, normaliems galvos smegenų MRT rezultatams prieš operaciją ir kai epilepsijos trukmè - <15 metų [7]. Šios metaanalizės, apimančios tiek vaikų, tiek suaugusiujų populiaciją, rezultatai parodè, kad maždaug pusei pacientų po operacijos nebesikartojo kritimai epilepsijos priepuolio metu (drop attacks), o penktadaliui priepuoliai visiškai išnyko [7]. Kita publikuota sisteminė apžvalga, sudaryta D. Graham ir kt., apima tik vaikų populiaciją (377 pacientai $<18 \mathrm{~m}$.) ir jos gauti rezultatai nurodo dar geresnes išeitis po CC, lyginant su anksčiau minėta metaanalize [10]. Ši studija išskiria rezultatus po dalinès ir totalinès kaliozotomijos ir juos palygina. Reikšmingas priepuolių dažnio sumažejjimas po totalinės kaliozotomijos stebimas $88 \%$ gydytụ vaikų, o po dalinès - $59 \%$ (stebejjimo laikotarpis po operacijos - ne mažesnis nei 12 mèn.) [10]. A. Y. Chan ir kt. bei kai kuriose kitose studijose pateikiami rezultatai neišskiria totalinès ir dalinès kaliozotomijos, todèl gaunamos prastesnès bendrosios išeitys po operacijos [7].

Klajoklio nervo stimuliacija (VNS) yra mažiau invazyvus VAE atoninių priepuolių paliatyvus gydymas nei kaliozotomija, tačiau dviejose sisteminėse apžvalgose, kuriose palyginamas VNS ir CC efektyvumas, nustatyta, kad po CC gaunamos reikšmingai geresnès išeitys nei po VNS. D. Rolston ir kt. 2015 m. apžvalga apima 26 straipsnius (317 CC ir 38 VNS pacientus) ir palygina šių operacijų išeitis pacientams, patiriantiems atoninius priepuolius su kritimu. Pacientų, kuriems buvo atlikta CC ir kuriems priepuoliai išnyko (58\%), buvo daugiau nei tų, kuriems priepuoliai išnyko po VNS implantavimo (21\%). Didesnis nei $50 \%$ priepuolių dažnio sumažèjimas taip pat dažniau stebimas po CC $(88,6 \%)$ nei po VNS implantavimo $(52,6 \%)$ [35]. Antroji metaanalizè, D. Lancman ir kt. atlikta 2013 m., taip pat apima 26 studijas (145 CC ir 293 VNS pa- cientus). Ši apžvalga nagrinèja išeitis po CC ir VNS implantavimo pacientams, kurie serga Lenokso-Gasto sindromu. Gauti rezultatai sutampa su anksčiau minėtos apžvalgos rezultatais: $>50 \%$ priepuolių dažnio sumažėjimas stebimas po CC $80 \%$ pacientų, o po VNS implantavimo $54,1 \%$ [36]. Abi apžvalgos apėmè tiek vaikų, tiek suaugusiųjų populiacijas ir duomenys pagal amžių nebuvo pateikti.

Apžvelgtos klinikinès studijos pateikia išvadas, kad CC yra efektyvus ir gerai toleruojamas paliatyvus VAE, ypač atoninių priepuolių, gydymas. Geriausi rezultatai gaunami esant jaunesniam amžiui priepuolių pradžios ir operacijos metu, esant mažiau nei 3 skirtingiems priepuolių tipams (efektyviausia infantiliniams spazmams, atoniniams ir toniniams priepuoliams) ir normaliems galvos smegenų MRT rezultatams prieš operaciją bei kai epilepsijos trukmè $-<15$ metų. Taip pat didesnis priepuolių sumažèjimas pastebimas po pilnos (totalinès) kaliozotomijos nei po dalinès.

\section{Gyvenimo kokybės pagerėjimas}

CC operacijos siekis yra ne tik sumažinti priepuolių dažni, bet ir pagerinti vaiko bei jo šeimos gyvenimo kokybę. Atlikti tyrimai rodo, kad tẻvų gyvenimo kokybės pagerèjimas koreliuoja su vaiko patiriamų priepuolių dažnio ir sunkumo sumažėjimu, dauguma tėvų po jų vaikams atliktos kaliozotomijos būna patenkinti [37]. Funkcinių vaiko galimybių ir elgesio pagerèjimas taip pat yra svarbus teigiamam gyvenimo kokybės vertinimui. D. Maehara ir kt. $2001 \mathrm{~m}$. atliktoje studijoje kasdienių veiklų atlikimo galimybės po kaliozotomijos pagerejo $62 \%$ vaikų. Vaiko elgesio pagerejjimas apima hiperaktyvumą (93\% jis sumažèjo), emocijas (42\% jos pagerèjo), socialinį elgesi ( $36 \%$ pagerèjo), kalbèjimą ir atminti (17\% pagerèjo) [38]. O 2007 m. D. Rathor ir kt. tyrime beveik trys ketvirtadaliai tèvų teigiamai įvertino savo vaikų pagerèjusi elgesị ir dèmesingumą po CC [39]. Taigi, kasdienè vaiko veikla po CC, įskaitant savarankiškumą, darnų gyvenimą šeimoje ir reikalingus gebejjimus mokykloje, gali labai pagerèti.

Kai kuriems pacientams, turintiems ryškų pažinimo ir kalbos funkcijų sutrikimą ir kuriems po atliktos CC stebimas teigiamas poveikis priepuoliams, taip pat pastebètas ir bendrojo intelekto bei kalbos gebejjimų pagerèjimas [38, 39]. Ši pagerèjimą greičiausiai lemia priepuolių dažnio sumažèjimas ir (ar) dėl to sumažèjęs VNE vartojimas. Gyve- 
nimo kokybės pagerėjimas po CC dažniau stebimas vaikų populiacijoje (>70 \%) nei suaugusiųų (apie $45 \%$ ), viena iš to priežasčių gali būti didesnis vaikų smegenų plastiškumas ir dèl to geriau veikiantys kompensaciniai mechanizmai [38].

\section{Operacijos komplikacijos}

Vaikams po CC rimtos ilgalaikès neigiamos pasekmės yra retos; dažniausiai nepageidaujamas operacijos poveikis yra trumpalaikis.

2016 m. atliktoje D. Rolston ir kt. CC komplikacijų apžvalgoje pateikti 236 operacijų duomenys ir nustatyta, kad komplikacijos pasireiškė 14,3 \% pacientų, dažniausiai pasitaikantis nepageidaujamas poveikis buvo trumpalaikis neurologinis deficitas dèl galvos smegenų pusrutulių atjungimo (disconnection sindromas), hemiparezè, ataksija, afazija ir kt. [40]. Literatūroje daug dèmesio skiriama galvos smegenų pusrutulių atjungimo (disconnection) sindromui. Šis trumpalaikis neurologinis deficitas apibrèžia elgesio pokyčius, kuriuos sukelia skaidulų, jungiančių abipus esančias galvos smegenų skirtingas dalis, atjungimas („svetimos“ ar „nesavos“ rankos sindromas, apraksija, taktilinė ar (ir) vizualinė anomija, agrafija, neglektas, disleksija ir kt.) [33, 41]. Suaugusiujuc ir vaiku populiacijoje ši komplikacija pastebèta $12,4 \%$ pacientų po dalinès CC ir $8,0 \%$ pacientų po totalinès CC [7]. Tačiau jau minètoje D. Graham ir kt. 2016 m. sisteminèje apžvalgoje, apimančioje tik vaikų populiaciją, šis sindromas pasireiškẻ 12,5\% ir buvo stebimas tik po totalinès CC, sindromo simptomai išnyko per 6 savaites po operacijos [10]. Nustatyta, kad sindromas dažniau pasireiškia po totalinès nei po dalinès CC.

2,7-5,9\% vaikų stebimos tokios pooperacinès komplikacijos, kaip karščiavimas, hematoma, hidrocefalija, subdurinis smegenų skysčio susikaupimas, infekcija (meningitas, osteomielitas) ar giliųjų venų trombozė [10].

Mirštamumas po CC siekia 0,2-2\% ir dažniausia to priežastis yra infekcinès komplikacijos, iš kurių dažniausia - pneumonija po operacijos [10, 42].

\section{VNE vartojimas po epilepsijos chirurginio gydymo}

VNE vartojimas po epilepsijos chirurginio gydymo yra dažnai diskutuojamas klausimas literatūroje. Pacientų ir gydytojų siekis yra ne tik kuo greičiau nutraukti jų vartojimą, bet ir išlaikyti gerą priepuolių kontrolę. Todèl gydytojams priimti teisingą sprendimą dèl VNE vartojimo po operacijos dažnai yra didelis iššūkis. Medikamentinio gydymo nutraukimas ar sumažinimas po operacijos ne tik palengvina pacientų ir jų šeimos finansinę naštą, bet yra naudingas neurologiniam vystymuisi bei mokymuisi, kas ypač svarbu vaikams [43, 44]. Atlikus gydytojų epileptologu apklausą, išsiaiškinta, kad laikas, kai pradedamas VNE vartojimo mažinimas po operacijos, yra labai skirtingas ir varijuoja nuo $<1 \mathrm{~m}$. iki $>2 \mathrm{~m}$., tam standartizuotų gairių nèra [45-47]. Kai kurie atlikti tyrimai rodo, kad per greitas VNE nutraukimas ar dozės sumažinimas po operacijos padidina priepuolių pasikartojimo riziką ir koreliuoja su ma- žesniu priepuolių išnykimu [48, 49], tačiau kituose tyrimuose ši koreliacija nenustatyta [50-52].

2014 m. R. Yardi ir kt. atlikta studija apie VNE vartojimo koregavimą po epilepsijos operacijos apima 609 pacientus (86\% - suaugusieji ir $14 \%$ - vaikai). $38 \%$ pacientų po operacijos buvo tęsiamas toks pats medikamentinis gydymas kaip ir prieš operaciją, $42 \%$ buvo sumažintos dozès, o $21 \%$ visiškai nutrauktas VNE vartojimas. Gauta, kad tiems, kuriems medikamentinis gydymas buvo nutrauktas praejjus 12 arba 24 mèn. po operacijos, priepuoliu pasikartojimo rizika per ateinančius 2 metus buvo 10-25\% didesnė nei tiems, kurie ši laikotarpi tęsė VNE vartojimą [53].

2018 m. atlikta L. Zhang ir kt. studija, kuri tyrẻ laikotarpio, kai pradedamas VNE nutraukimas po operacijos (timing inerval to start AED withdraw, TWI), koreliaciją su priepuolių pasikartojimo dažniu po operacijos, apima 205 pacientus (suaugusieji ir vaikai), iš kurių 77 pacientams buvo tęsiamas VNE vartojimas po operacijos, o 128 buvo mažinamos dozès [54]. Iš jų 35 pacientams TWI buvo $<1 \mathrm{~m}$., 32 pacientams $-1-2 \mathrm{~m}$. ir $48-<2 \mathrm{~m}$. Tyrimo stebejjimo mediana buvo 52 mèn. po operacijos ir 36 mèn. po vaistų nutraukimo. Pacientų, kuriems priepuoliai nepasikartojo praejjus vieneriems, dvejiems ar trejiems metams po VNE vartojimo sumažinimo, buvo atitinkamai - 79 \%, $83 \%$ ir $81 \%$. Paskutinio stebejjimo metu $86 \%$ pacientu priepuoliai nepasikartojo. Nustatyta, kad priepuolių nebuvimo dažnis reikšmingai nesiskyrè tarp grupių su skirtingais TWI, praejus vieneriems, dvejiems ar trejiems metams po VNE vartojimo sumažinimo. Kitoje 2018 m. publikuotoje B. Schmeiser ir kt. analizėje, kuri apėmė 532 pacientus (suaugusieji ir vaikai), koreliacija tarp vartojamų VNE po operacijos sumažinimo ar padidinimo ir priepuolių dažnio po operacijos taip pat nenustatyta [52].

Anksčiau aptartuose klinikiniuose tyrimuose ir sisteminėse apžvalgose daroma išvada, kad kaliozotomija yra saugus ir efektyvus vaistams atsparios epilepsijos gydymas tiek vaikams, tiek suaugusiesiems. Aprašytų vaikų klinikinių atvejų baigtys po kaliozotomijos yra skirtingos. Pirmojo atvejo baigtis yra sėkminga ir, praejus $4 \mathrm{~m}$. po atliktos operacijos, priepuoliai nebesikartoja. Jau minètame vaikų klinikiniame tyrime nustatyta, kad, jei priepuoliai nepasikartoja per 12 mèn. po operacijos, tikètina, kad jie nepasikartos ir véliau [32]. Tačiau antrasis atvejis nebuvo sėkmingas - praejjus 7 mèn. po operacijos, buvo pradėta mažinti VNE dozes ir priepuoliai pradejo kartotis. Remiantis minėta studija, tikètina, kad šiam pacientui priepuoliai ir toliau bus sunkiai kontroliuojami.

Pirmojo atvejo pacientė operacijos metu buvo jaunesnio amžiaus ( $5 \mathrm{~m}$.) nei antrojo atvejo pacientas (10 m.), kas tiesiogiai koreliuoja su geresne prognoze. Taip pat jai pasireiškè vieno tipo priepuoliai (židininiai su greita generalizacija), kai antrajam pacientui - kelių (miokloniniai, toniniai-kloniniai, židininiai ir infantiliniai spazmai). Pagal atliktus klinikinius tyrimus, geresni rezultatai po kalosotomijos būna esant mažiau nei 3 skirtingiems priepuolių tipams.

Operacijos komplikacijos nepasireiškè nè vienam iš aprašytų pacientų. 


\section{IŠVADOS}

Darbe apžvelgiami epilepsijos gydymo kaliozotomija klinikinių tyrimų rezultatai, gydant vaistams atsparią epilepsiją, ir aprašomi du pediatriniai pacientai su skirtingomis išeitimis po operacijos, gydyti Vilniaus universiteto ligoninès Santaros klinikų Vaikų neurologijos ir neurochirurgijos skyriuose.

Kaliozotomija turètų būti svarstoma kaip paliatyvus epilepsijos gydymo metodas vaikams, kuriems pasireiškia dažni, vaistams nuo epilepsijos atsparūs epilepsijos priepuoliai, darantys neigiamą poveiki jų gyvenimui ir trukdantys jų pažintinei bei psichosocialinei raidai. Gerai sukontroliuoti priepuoliai ne tik pagerina vaiko sveikatos būklę, bet ir mažina socialinę atskirtị bei padeda integruotis ị edukacinę veiklą. Kaliozotomija gali būti efektyvus vaistams atsparios epilepsijos gydymas vaikams, kai rezekcinė operacija yra negalima; jos efektyvumas vaikams siekia iki $88 \%$, o komplikacijų rizika yra maža.

Publikuotų klinikinių studijų duomenimis, geriausi rezultatai pasiekiami esant jaunesniam amžiui operacijos metu, kai pasireiškia mažiau nei 3 skirtingi priepuolių tipai ir kai epilepsijos trukmé - <15 metų. Kai kuriose studijose didesnis priepuolių sumažejimas dažniau buvo pasiektas po totalinès kaliozotomijos nei po dalinès.

\section{Literatūra}

1. Kèvalas R. Pediatrija. III dalis. Kaunas: Vitae Litera, 2018.

2. Wilfong A. Seizures and epilepsy in children: refractory seizures and prognosis [Internet] 2020. [cited 2020 Apr 16]. Available from: https://www.uptodate.com/contents/ seizures-and-epilepsy-in-children-refractory-seizures-andprognosis

3. Kwan P, Arzimanoglou A, Berg AT, Brodie MJ, Hauser WA, Mathern G, et al. Definition of drug resistant epilepsy: consensus proposal by the ad hoc Task Force of the ILAE Commission on Therapeutic Strategies. Epilepsia 2010; 51(6): 1069-77. https://doi.org/10.1111/j.1528-1167. 2009.02397.x

4. Sirven JI. Evaluation and management of drug-resistant epilepsy [Internet] 2018. [cited 2020 Apr 16]. Available from: https://www.uptodate.com/contents/evaluation-andmanagement-of-drug-resistant-epilepsy

5. Sheng J, Liu S, Qin H, Li B, Zhang X. Drug-resistant epilepsy and surgery. Curr Neuropharmacol 2018; 16(1): 17-28. https://doi.org/10.2174/1570159X15666170504123316

6. Benbadis SR, Tatum WO, Vale FL. When drugs don't work: an algorithmic approach to medically intractable epilepsy. Neurology 2000; 55(12): 1780-4. https://doi.org/10.1212/ WNL.55.12.1780

7. Chan AY, Rolston JD, Lee B, Vadera S, Englot DJ. Rates and predictors of seizure outcome after corpus callosotomy for drug-resistant epilepsy: a meta-analysis. J Neurosurg 2019; 130(4): 1193-202. https://doi.org/10.3171/2017.12. JNS172331

8. Asadi-Pooya AA, Sharan A, Nei M, Sperling MR. Corpus callosotomy. Epilepsy Behav 2008; 13(2): 271-8. https://doi.org/10.1016/j.yebeh.2008.04.020

9. Fisher RS, Acevedo C, Arzimanoglou A, Bogacz A, Cross JH, Elger CE, et al. ILAE Official Report: a practical clinical definition of epilepsy. Epilepsia 2014; 55(4): 475-82. https://doi.org/10.1111/epi.12550

10. Graham D, Tisdall MM, Gill D. Corpus callosotomy outcomes in pediatric patients: a systematic review. Epilepsia 2016; 57(7): 1053-68. https://doi.org/10.1111/epi.13408

11. Wilfong A. Seizures and epilepsy in children: classification, etiology, and clinical features [Internet] 2018. [cited 2020 Apr 16]. Available from: https://www.uptodate.com/ contents/seizures-and-epilepsy-in-children-classificationetiology-and-clinical-features

12. Fisher RS, Cross JH, French JA, Higurashi N, Hirsch E, Jansen FE, et al. Operational classification of seizure types by the International League Against Epilepsy: Position Paper of the ILAE Commission for Classification and Terminology. Epilepsia 2017; 58(4): 522-30. https://doi.org/10.1111/ epi. 13670

13. Scheffer IE, Berkovic S, Capovilla G, Connolly MB, French J, Guilhoto L, et al. ILAE classification of the epilepsies: Position paper of the ILAE Commission for Classification and Terminology. Epilepsia 2017; 58(4): 512-21. https://doi.org/10.1111/epi.13709

14. Steinbok P, Gan PYC, Connolly MB, Carmant L, Sinclair DB, Rutka J, et al. Epilepsy surgery in the first 3 years of life: a Canadian survey. Epilepsia 2009; 50(6): 1442-9. https://doi.org/10.1111/j.1528-1167. 2008.01992.x

15. Kiriakopoulos E. Atonic seizures. Epilepsy Foundation [Internet]. 2017. [cited 2020 Apr 16]. Available from: https://www.epilepsy.com/learn/types-seizures/atonicseizures

16. Dorfmüller G, Delalande O. Pediatric epilepsy surgery. In: Dulac O, Lassonde M, Sarnat HB, eds. Handbook of Clinical Neurology. Vol. 111: Pediatric Neurology, Part I. Elsevier, 2013; 785-95. https://doi.org/10.1016/B978-0-444-528919.00081-6

17. Subačiūtė J. Neurochirurgija. Kaunas: Naujasis lankas, 2016.

18. Oguni H, Olivier A, Andermann F, Comair J. Anterior callosotomy in the treatment of medically intractable epilepsies: a study of 43 patients with a mean follow-up of 39 months. Ann Neurol 1991; 30(3): 357-64. https://doi.org/10.1002/ ana.410300307

19. Mathews MS, Linskey ME, Binder DK. William P. van Wagenen and the first corpus callosotomies for epilepsy. J Neurosurg 2008; 108(3): 608-13. https://doi.org/10.3171/ JNS/2008/108/3/0608

20. Wagenen WPV, Herren RY. Surgical division of commissural pathways in the corpus callosum: relation to spread of an epileptic attack. Arch Neurol Psychiatry 1940; 44(4): 740-59. https://doi.org/10.1001/archneurpsyc.1940. 02280100042004

21. Musiek FE. Neuroanatomy, neurophysiology, and central auditory assessment. Part III: Corpus callosum and efferent pathways. Ear Hear 1986; 7(6): 349-58. https://doi.org/ 10.1097/00003446-198612000-00001

22. Spencer SS, Spencer DD, Sass K, Westerveld M, Katz A, Mattson R. Anterior, total, and two-stage corpus callosum section: differential and incremental seizure responses. Epilepsia 1993; 34(3): 561-7. https://doi.org/10.1111/ j.1528-1157.1993.tb02596.x

23. Chang EF, Rowland NC, Barbaro NM. Corpus callosotomy: indications and techniques. In: Quiñones-Hinojosa A, ed. Schmidek and Sweet: operative neurosurgical techniques. 
6th edition. Philadelphia: W.B. Saunders, 2012; 1295-9. https://doi.org/10.1016/B978-1-4160-6839-6.10112-1

24. Cascino GD. Surgical treatment of epilepsy in adults [Internet] 2019. [cited 2020 Mar 31]. Available from: https://www.uptodate.com/contents/surgical-treatment-ofepilepsy-in-adults

25. Baxendale S, Wilson SJ, Baker GA, Barr W, Helmstaedter C, Hermann BP, et al. Indications and expectations for neuropsychological assessment in epilepsy surgery in children and adults. Report of the ILAE Neuropsychology Task Force Diagnostic Methods Commission: 2017-2021 Neuropsychological assessment in epilepsy surgery. Epileptic Disord 2019; 21(3): 221-34. https://doi.org/10.1111/ epi.16309

26. Moeller J, Haider HA, Hirsch LJ. Electroencephalography (EEG) in the diagnosis of seizures and epilepsy [Internet] 2019. [cited 2020 Mar 31]. Available from: https://www.uptodate.com/contents/electroencephalographyeeg-in-the-diagnosis-of-seizures-and-epilepsy

27. Jayalakshmi S, Vooturi S, Gupta S, Panigrahi M. Epilepsy surgery in children. Neurol India 2017; 65(3): 485-92. https://doi.org/10.4103/neuroindia.NI_1033_16

28. Luat AF, Asano E, Kumar A, Chugani HT, Sood S. Corpus callosotomy for intractable epilepsy revisited: the Children's Hospital of Michigan series. J Child Neurol 2017; 32(7): 624-9. https://doi.org/10.1177/0883073817697847

29. Itamura $S$, Okanishi T, Nishimura $M$, Kanai $S$, Baba $S$, Masuda Y, et al. Analysis for the association between corpus callosum thickness and corpus callosotomy outcomes for patients with epileptic spasms or tonic spasms. Pediatr Neurol 2019; 95: 79-83. https://doi.org/10.1016/j.pediatrneurol. 2019.01.012

30. Hong J, Desai A, Thadani VM, Roberts DW. Efficacy and safety of corpus callosotomy after vagal nerve stimulation in patients with drug-resistant epilepsy. J Neurosurg 2017; 128(1): 277-86. https://doi.org/10.3171/2016.10. JNS161841

31. Iwasaki M, Uematsu M, Hino-Fukuyo N, Osawa S, Shimoda Y, Jin K, et al. Clinical profiles for seizure remission and developmental gains after total corpus callosotomy. Brain Dev 2016; 38(1): 47-53. https://doi.org/10.1016/ j.braindev.2015.04.010

32. Lien ND, Tuan DA, Hung CV, Lepard JR, Rocque BG. Corpus callosotomy for treatment of drug-resistant epilepsy: a review of 16 pediatric cases in northern Vietnam. J Neurosurg Pediatr 2020; 25(6): 582-7. https://doi.org/ 10.3171/2019.12.PEDS19638

33. Graham D, Gill D, Dale RC, Tisdall MM, Corpus Callosotomy Outcomes Study Group. Seizure outcome after corpus callosotomy in a large paediatric series. Dev Med Child Neurol 2018; 60(2): 199-206. https://doi.org/10.1111/ dmcn. 13592

34. Chuandong L, Yufei T, Hua M, Tao G, Yali D, Xiangyong Y, et al. Corpus callosotomy for patients with intractable seizures. Journal of Craniofacial Surgery 2015; 26(8): e795-8. https://doi.org/10.1097/SCS.0000000000002162

35. Rolston JD, Englot DJ, Wang DD, Garcia PA, Chang EF. Corpus callosotomy versus vagus nerve stimulation for atonic seizures and drop attacks: a systematic review. Epilepsy Behav 2015; 51: 13-7. https://doi.org/10.1016/ j.yebeh.2015.06.001

36. Lancman G, Virk M, Shao H, Mazumdar M, Greenfield JP, Weinstein S, et al. Vagus nerve stimulation vs. corpus callosotomy in the treatment of Lennox-Gastaut syndrome: a meta-analysis. Seizure 2013; 22(1): 3-8. https://doi.org/ 10.1016/j.seizure.2012.09.014

37. Iwasaki M, Uematsu M, Nakayama T, Hino-Fukuyo N, Sato Y, Kobayashi T, et al. Parental satisfaction and seizure outcome after corpus callosotomy in patients with infantile or early childhood onset epilepsy. Seizure 2013; 22(4): 303-5. https://doi.org/10.1016/j.seizure.2013.01.005

38. Maehara T, Shimizu H. Surgical outcome of corpus callosotomy in patients with drop attacks. Epilepsia 2001; 42(1): 67-71. https://doi.org/10.1046/j.1528-1157. 2001.081422.x

39. Rathore C, Abraham M, Rao RM, George A, Sankara Sarma P, Radhakrishnan K. Outcome after corpus callosotomy in children with injurious drop attacks and severe mental retardation. Brain Dev 2007; 29(9): 577-85. https://doi.org/10.1016/j.braindev.2007.03.008

40. Rolston JD, Englot DJ, Knowlton RC, Chang EF. Rate and complications of adult epilepsy surgery in North America: analysis of multiple databases. Epilepsy Res 2016; 124: 55-62. https://doi.org/10.1016/j.eplepsyres. 2016.05.001

41. Mendoza JE. Disconnection syndrome. In: Kreutzer JS, DeLuca J, Caplan B, eds. Encyclopedia of clinical neuropsychology. New York, NY: Springer, 2011. https://doi.org/10.1007/978-0-387-79948-3_682

42. Shimizu H. Our experience with pediatric epilepsy surgery focusing on corpus callosotomy and hemispherotomy. Epilepsia 2005; 46(s1): 30-1. https://doi.org/10.1111/ j.0013-9580.2005.461009.x

43. Boshuisen K, van Schooneveld MMJ, Uiterwaal CSPM, Cross JH, Harrison S, Polster T, et al. Intelligence quotient improves after antiepileptic drug withdrawal following pediatric epilepsy surgery. Ann Neurol 2015; 78(1): 104-14. https://doi.org/10.1002/ana.24427

44. van Schooneveld MM, van Erp N, Boshuisen K, Meekes J, Braun KP. Withdrawal of antiepileptic drugs improves psychomotor speed after childhood epilepsy surgery. Epilepsy Research 2013; 107(1-2): 200-3. https://doi.org/ 10.1016/j.eplepsyres.2013.08.004

45. Téllez-Zenteno JF, Ronquillo LH, Jette N, Burneo JG, Nguyen DK, Donner EJ, et al. Discontinuation of antiepileptic drugs after successful epilepsy surgery. A Canadian survey. Epilepsy Res 2012; 102(1): 23-33. https://doi.org/ 10.1016/j.eplepsyres.2012.04.018

46. Berg AT, Langfitt JT, Spencer SS, Vickrey BG. Stopping antiepileptic drugs after epilepsy surgery: a survey of US epilepsy center neurologists. Epilepsy Behav 2007; 10(2): 219-22. https://doi.org/10.1016/j.yebeh.2006.12.001

47. Swisher CB, Sinha SR. Survey of current practices among US epileptologists of antiepileptic drug withdrawal after epilepsy surgery. Epilepsy Behav 2013; 26(2): 203-6. https://doi.org/10.1016/j.yebeh.2012.11.053

48. Ziemba KS, Wellik KE, Hoffman-Snyder C, Noe KH, Demaerschalk BM, Wingerchuk DM. Timing of antiepileptic drug withdrawal in adult epilepsy patients after neocortical surgical resection: a critically appraised topic. Neurologist 2011; 17(3): 176-8. https://doi.org/10.1097/ NRL.0b013e318217368e

49. Park K-I, Lee SK, Chu K, Jung K-H, Bae E-K, Kim J-S, et al. Withdrawal of antiepileptic drugs after neocortical epilepsy surgery. Ann Neurol 2010; 67(2): 230-8. https://doi.org/ 10.1002/ana.21884

50. Boshuisen K, Arzimanoglou A, Cross JH, Uiterwaal CSPM, Polster T, van Nieuwenhuizen O, et al. Timing of antiepilep- 
tic drug withdrawal and long-term seizure outcome after paediatric epilepsy surgery (TimeToStop): a retrospective observational study. Lancet Neurol 2012; 11(9): 784-91. https://doi.org/10.1016/S1474- 4422(12)70165-5

51. Pimentel J, Peralta AR, Campos A, Bentes C, Ferreira AG. Antiepileptic drugs management and long-term seizure outcome in post surgical mesial temporal lobe epilepsy with hippocampal sclerosis. Epilepsy Res 2012; 100(1-2): 55-8. https://doi.org/10.1016/j.eplepsyres.2012.01.010

52. Schmeiser B, Steinhoff BJ, Schulze-Bonhage A. Does early postoperative drug regimen impact seizure control in patients undergoing temporal lobe resections? J Neurol 2018; 265(3): 500-9. https://doi.org/10.1007/s00415-017-8700-z

53. Yardi R, Irwin A, Kayyali H, Gupta A, Nair D, GonzalezMartinez J, et al. Reducing versus stopping antiepileptic medications after temporal lobe surgery. Ann Clin Trans Neurol 2014; 1(2): 115-23. https://doi.org/10.1002/acn3.35

54. Zhang L, Jiang X-Y, Zhou D, Zhang H, Bao S-M, Li J-M. Postoperative seizure outcome and timing interval to start antiepileptic drug withdrawal: A retrospective observational study of non-neoplastic drug resistant epilepsy. Sci Rep 2018; 8: 13782. https://doi.org/10.1038/s41598-01831092-3

R. Matonytė, S. Ročka, J. Grikinienė

CORPUS CALLOSOTOMY FOR TREATMENT OF PEDIATRIC EPILEPSY: TWO CLINICAL CASES AND A LITERATURE REVIEW

\section{Summary}

Epilepsy is one of the most common chronic diseases in children and it affects approximately 6.1 per 1000 children in Lithuania as of 2018 data. The onset of epilepsy most often develops in children and older adults. The condition of epilepsy may be traced to various factors and seizure symptoms can vary widely. Controlled seizures are the main goal of epilepsy management. Children with uncontrolled seizures may develop speech, language, cognitive and behavioral dysfunction epileptic encephalopathies. Effective management of epilepsy in children not only improves condition of health, but also reduces social exclusion and helps integrate into educational activities. However, even if the disease is diagnosed early and appropriate antiepileptic drug therapy is prescribed, epileptic seizures persist in $20-40 \%$ of patients. For some of these patients, surgical treatment of epilepsy, such as resection or palliative surgery, may be effective in reducing seizures. Resection of a localized epileptogenic focus is an effective treatment for appropriate refractory cases. However, not all patients are candidates for the resection, for example, in the case of multifocal or rapidly generalizing seizures without a clearly identified epileptogenic focus. One of the most effective treatment for refractory epilepsy is corpus callosotomy. The corpus callosum is the most important pathway for the spread of epileptic activity between the two hemispheres of the brain. Its cutting precludes epileptic discharges from traveling between hemispheres (i.e., generalization). Overall, long-term follow-up studies after callosotomy have shown improvement in $80-90 \%$ of patients (seizure-free or reduction). The paper describes two pediatric patients treated in Vilnius University Hospital Santara Clinics, Department of Pediatric Neurology and Neurosurgery, who underwent a corpus callosotomy, and compares the outcome of these clinical cases with the results of recent clinical trials.

Keywords: refractory epilepsy, pediatrics, epilepsy surgery, corpus callosotomy.

Gauta:

20200517
Priimta spaudai:

20200524 